\title{
MIKE BASIN Based Decision Support Tool for Water Sharing and Irrigation Management in Rangawan Command of India
}

\author{
R. K. Jaiswal, ${ }^{1}$ N. C. Ghosh, ${ }^{2}$ Poonam Guru, ${ }^{3}$ and Devakant ${ }^{4}$ \\ ${ }^{1}$ National Institute of Hydrology, WALMI Campus, Kolar Road, Bhopal, Madhya Pradesh 462016, India \\ ${ }^{2}$ National Institute of Hydrology, Jal Vigyan Bhawan, Roorkee, Uttarakhand 247667, India \\ ${ }^{3}$ Agriculture Technology Management Agency, Damoh, Madhya Pradesh 470661, India \\ ${ }^{4} J a w a h a r l a l ~ N e h r u$ Krishi Vishva Vidalaya, Jabalpur, Madhya Pradesh 482004, India
}

Correspondence should be addressed to R. K. Jaiswal; rkjaiswal_sagar@yahoo.co.in

Received 4 April 2014; Revised 29 May 2014; Accepted 25 June 2014; Published 22 July 2014

Academic Editor: John S. Swanston

Copyright (C) 2014 R. K. Jaiswal et al. This is an open access article distributed under the Creative Commons Attribution License, which permits unrestricted use, distribution, and reproduction in any medium, provided the original work is properly cited.

In this study, MIKE BASIN has been used as a decision support tool for irrigation management and water sharing of Rangawan reservoir, an interstate project of Madhya Pradesh and Uttar Pradesh in India. The water sharing and optimum irrigation releases have been analyzed by developing two separate models in decision support tool; the first model computes irrigation demand and offers inputs to the second model, which calculates water supplies and deficits as per the water sharing agreements between the two states. The models have been used to generate twelve different scenarios for evaluation of irrigation demands, water supply, and demand deficit/excess for actual cropping pattern in command of Madhya Pradesh part. Simulated results showed, in average/wet rainfall year with conveyance efficiency of $60 \%$ and application efficiency of $70 \%$, the irrigation demand of $11.83 \mathrm{Mm}^{3}$ has been found satisfying without any deficit. By improving efficiencies, conjunctive use, and managing irrigation supplies as recommended from scenarios of DSS application, more areas in the command can be brought under irrigation. The developed models can be used for real time reservoir operation and irrigation planning under variable climatic conditions, conveyance and application efficiencies, consumptive use of surface and groundwater, and probable runoff and cropping pattern.

\section{Introduction}

Reservoir operation involves many decision variables and multiple objectives as well as risk and uncertainty. In addition, conflicting objectives lead to significant challenges for operators in making operational decisions. Traditionally, fixed reservoir rule curves are used for guiding and managing the reservoir operation. These curves specify reservoir releases according to different controls such as current reservoir levels, hydrological conditions, water demands, and time of a year. Established rule curves, however, are often not very efficient for balancing the demands of different users [1-3]. Optimization and simulation of reservoir system are preferred methods in reservoir operation and irrigation management. Optimization is a powerful technique that helps to analyze complex water resource system for obtaining the most economical/viable solution. In many situations, decision makers would be interested in examining a number of scenarios rather than just looking at one single solution that is optimal [4]. Thus, there is a potential for improvement of reservoir operating policy with the help of optimization or development and examination of scenarios. Various operating models and decision support systems (DSS) have been developed and applied by researchers to address the issues of water supply from reservoirs for irrigation planning, flood management, power generation, multiobjective operation, and enhancement of efficiencies [5-24]. The development of DSS and generation of scenarios help project authority to take appropriate decisions on operation of reservoirs and to suggest farmers for changing crop pattern in dry or low rainfall years.

A DSS is normally developed for reservoir water management conflict resolution (RWM-CRSS) for a multipurpose single reservoir system, which consists of communication 
database management and a model-base management system [25]. The utility of remote sensing and geographic information system (GIS) environment had been found effective for determining realistic irrigation demands and reservoir operation of Samrat Ashok Sagar Reservoir in India. Using simulation analysis of 29-year inflow data, rule curves were derived for operation of reservoir to meet demands for water deficit areas in advance to avoid severe crop failure [26]. FAO's "CROPWAT" model was applied using agrometeorological and remote sensing data (1986-1998 and 2008) to calculate irrigation water requirements of wheat and mustard crops grown in western Yamuna canal command [27]. The major problem in reservoir operation has been found to be improper distribution of water in head and tail reaches. In drought years, conjunctive use of surface and groundwater can play an important role in mitigating demand deficit in command areas. Two separate models, namely, groundwater balance and groundwater management model, were applied to determine optimum cropping pattern and groundwater allocation from private and government owned tube wells based on different soils, agriculture, and seasons [28]. A multiobjective genetic algorithm (MOGA), constrained differential dynamic programming (CDDP), and the groundwater simulation model ISOQUAD were developed for multiobjective conjunctive use planning of surface and subsurface water using genetic algorithm and dynamics programming [29]. A simulation-optimization model for conjunctive use of surface water and groundwater on a basin-wide scale in the Najafabad plain of west-central Iran was developed for optimum planning. The results of the model demonstrated the importance of the conjunctive use approach for planning and management of water resources in semiarid regions [30].

MIKE BASIN developed by DHI [31], which is a multipurpose, GIS-based river basin simulation package, has the capability to analyze water sharing problems and environmental issues. The MIKE BASIN simulation model was applied by many investigators, for example, for river water management in Mun river basin located in northeastern Thailand [32] and MIKE 11 for analysis of reservoir flood control operation rules in Hoa Binth reservoir in Vietnam [33]. Review of the literature revealed most of the studies dealt with deriving an optimal solution under predefined constraints related to actual field conditions. It is noted that the optimum solution sometimes failed to provide solution to complex real world situations. This motivated the study to generate different scenarios of demand, supply, climate, efficiencies, and conjunctive use of surface and groundwater for deriving operating schedule to achieve maximum benefits from a reservoir.

\section{Study Area and Data Used}

The Rangawan dam project, a major inter-state irrigation project of Madhya Pradesh (MP) and Uttar Pradesh (UP) in India, operates under an agreement of water sharing, which states that MP can utilize $56.63 \mathrm{Mm}^{3}$ water for kharif crops up to 31 October of each year and the balance available on 1 November can be divided between MP and UP in the ratio of $15: 36$. The Rangawan dam is an earthen dam located near village Rangawan of Chhatarpur district in MP. The length of the dam is $1.83 \mathrm{~km}$ with catchment area of about $731.70 \mathrm{~km}^{2}$. The gross storage capacity of the Rangawan reservoir is $163.57 \mathrm{Mm}^{3}$ with live storage capacity and dead storage capacity of $156.08 \mathrm{Mm}^{3}$ and $7.50 \mathrm{Mm}^{3}$, respectively. The reservoir and its command in MP are in Figure 1. The designed cropping pattern in MP part consists of 5600 ha wheat and 878 ha gram in rabi and 10500 ha soybean and 107 ha paddy in kharif season. The existing cropping pattern with canal irrigation in the average/wet rainfall years consists of 2820.71 ha wheat and 1819.84 ha gram in rabi.

The rainfall data of 21 years (1988-2008) of Rajnagar block have been analyzed. Two representative years, the year 1997 having $1075 \mathrm{~mm}$ annual rainfall as wet/average rainfall year and the other year 2005 having annual rainfall $798.70 \mathrm{~mm}$ as dry year, have been used as indicative years for estimation of crop water requirement as per the guidelines of FAO [34]. Reservoir details such as river bed level, dam crest level, top of dead storage, and flood control level have been used for defining reservoir properties. The soils in the commands of Rangawan reservoir on nine sites have been tested to determine field capacity, wilting point, initial water content, depth of evaporable layer, and porosity. The details of actual cropping pattern under canal irrigation from Rangawan reservoir in MP part given in Table 1 have been used to estimate crop water requirement.

\section{Objectives of the Study}

The Rangawan reservoir supplies irrigation water to both MP and UP. The MP part of this region experiences frequent drought and losses in conveyance and application due to uneven topography, unlined canals, and poor conditions of outlets. Management of water in UP part is comparatively better due to good canal/delivery system and flat topography. The management authority in MP faces the problem of nonsupplying optimum and assured water during rabi crops due to lack of proper operation plan that leads to huge losses to farmers. To derive a judicious operation guideline of the reservoir under the existing water sharing policy between the two states, the study is carried out with the following objectives:

(i) rainfall and reservoir storage analysis for identification of dry, average/wet rainfall years and inflows to the reservoir;

(ii) application of MIKE BASIN model as a decision support tool to address water sharing issue and irrigation management on real time basis;

(iii) scenario based demand-supply assessment under variable climate, reservoir storage, efficiencies, and conjunctive use conditions in MP part.

\section{MIKE BASIN Model}

MIKE BASIN works on digitized river network that can be generated with the help of digital elevation model (DEM) 


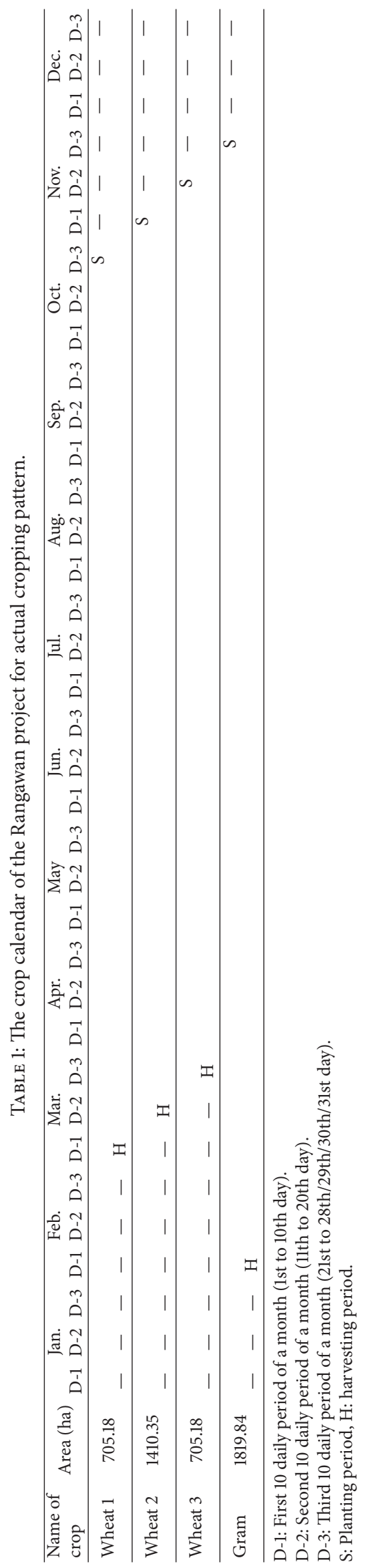




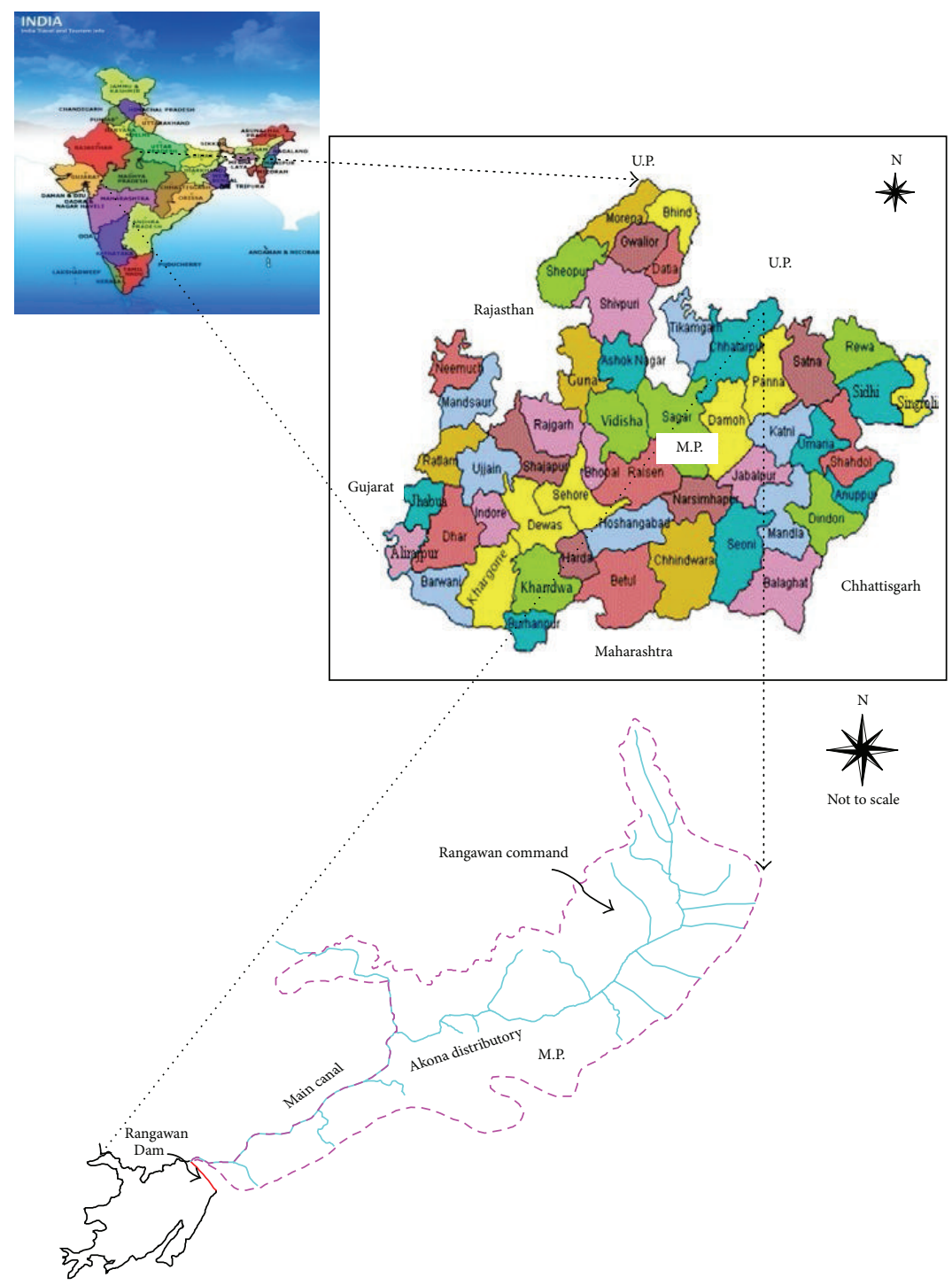

FIGURE 1: Base map of the study area.

or schematic river network in which reservoir nodes can be connected to command, hydropower, and water user nodes through channels. MIKE BASIN can accommodate multiple multipurpose reservoir systems or individual reservoir to simulate the performance of specified operating policies using associated operating rule curves. The reservoirs set in MIKE BASIN model can be run either as rule curve reservoirs, allocation pool reservoir, or as lake. The general and operation properties consist of elevation-area-capacity table, characteristics levels of reservoirs, losses, rule curves, flood control zones, minimum operating zones, reduction level and reduction percentages, remote flow rule, and priorities to operate reservoirs as per management policies. For setting the irrigation model in MIKE BASIN, various submodels need to be developed which can be used in combination to define the heterogeneity of soil, climate, irrigation methods, and crop sequence in the command. The climate, reference evapotranspiration (ET), soil water, runoff (optional), irrigation method, crop, yield (optional), and crop sequence submodels are used to determine crop water requirement and yield. The climate submodel accepts a number of commonly available climate inputs and converts them into the input required by reference ET submodel. The reference ET submodel provides reference evapotranspiration to crop submodel at each time step of simulation. The main task of the soil water model is to keep track of the amount of soil water available for soil evaporation and crop evapotranspiration at any time during the simulation.

The runoff submodel helps to compute fraction of the precipitation leaving the field as surface runoff and not entering the root zone. If no selection is made the runoff is assumed to be zero. The irrigation submodel facilitates to specify how and when a given field is irrigated. The irrigation model requires a wetting fraction that determines the fraction of the field surface that is wetted during irrigation. The crop submodel helps compute crop evapotranspiration 


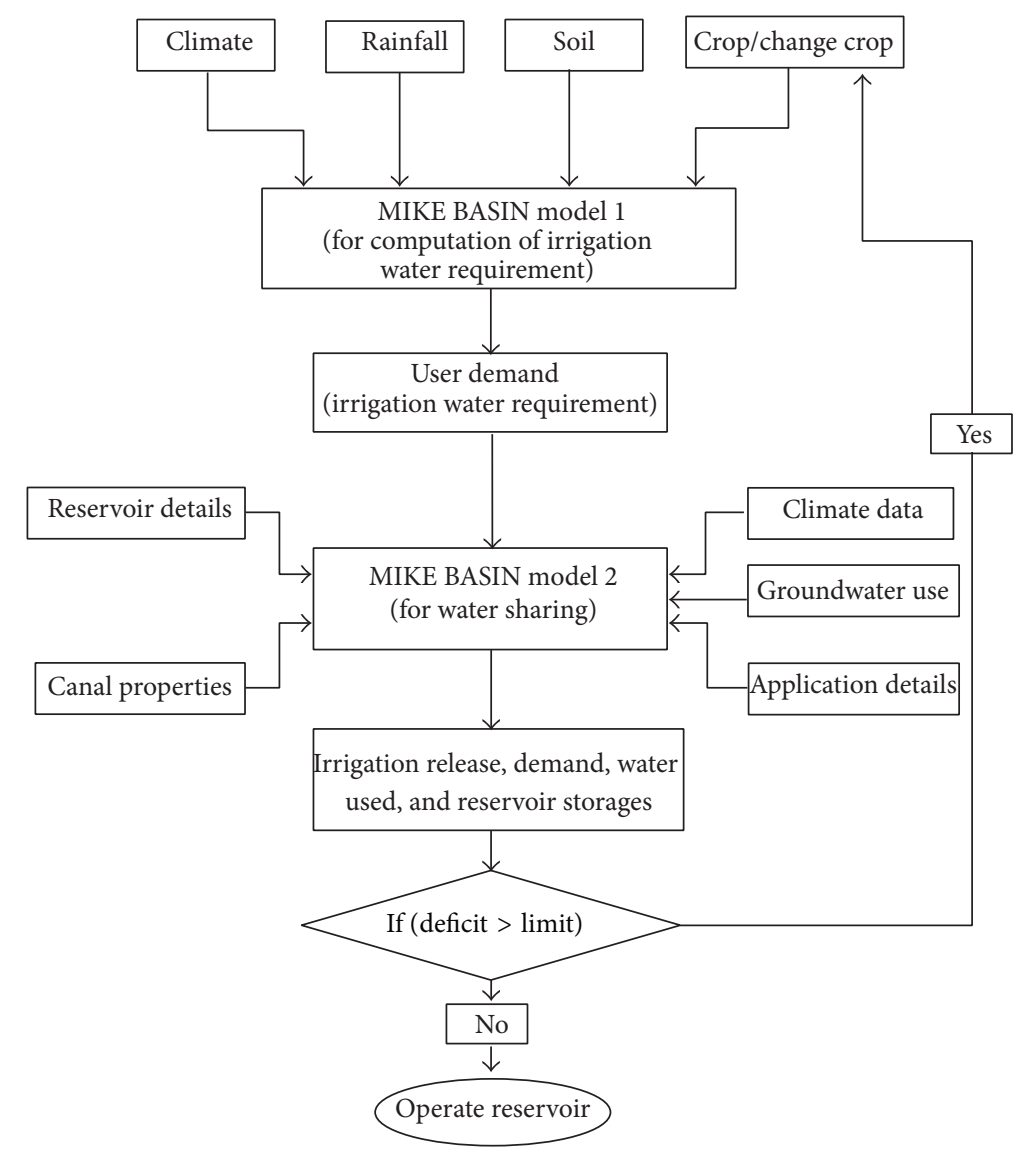

FIGURE 2: Flow chart for development of DSS for opeartion of the Rangawan reservoir.

and soil evaporation for crops using soil moisture content and reference evapotranspiration with dual crop coefficient model. The basal crop coefficient $\left(K_{\mathrm{cb}}\right)$ that is defined as the ratio of the crop evapotranspiration over the reference evapotranspiration $\left(\mathrm{ET}_{c} / \mathrm{ET}_{\mathbf{0}}\right)$ is assumed as constant in the initial and middle stages and considered to follow a linear variation between the stages. The root depth $(R)$ determines the depth from which the crop can extract water and is assumed to attain the maximum depth $\left(R_{\max }\right)$ at the beginning of the middle stage. The variation between the initial depth and the maximum depth is determined by the following relationship:

$$
R=\frac{\left(K_{\mathrm{cb}}-K_{\mathrm{cb}, \text { ini }}\right)}{\left(K_{\mathrm{cb}, \text { mid }}-K_{\mathrm{cb}, \text { ini }}\right)}\left(R_{\mathrm{max}}-R_{\min }\right)+R_{\mathrm{min}}
$$

where $K_{\mathrm{cb} \text {,ini }}$ is the initial basal coefficient, $K_{\mathrm{cb} \text {,mid }}$ is the basal crop coefficient in the middle stage, and $R_{\min }$ is the minimum root depth. The MIKE BASIN model uses FAO 33 yield model, which computes potential crop yield $\left(Y_{p}\right)$ under optimal conditions (no soil moisture stress). A crop sequence is not a submodel but a convenient way to specify how a field is managed. An irrigation node represents an area comprising one or more irrigation fields, which draw water from the same source(s). The irrigation node represents the total irrigation demand of the fields and optionally the crop yield. Based on the calculated demand, water is extracted from one or more sources, for example, river nodes and/or reservoirs according to the specified allocation rules. The channels are the segments that connect water users, irrigation nodes, and hydropower nodes to a river or a reservoir. The flow losses and flow capacity time series are optional time series required to define loss/gain of water due to seepage and evaporation loss. The MIKE BASIN model has a lot of capabilities of modeling, water transfer, crop water computation, groundwater, and water quality assessment; still it cannot simulate if an allocation pool reservoir is connected with irrigation node. To overcome this shortcoming, two separate MIKE BASIN models have been developed where first model computes the irrigation demand of Rangawan command. The irrigation demands computed from the first model have been used as demand of user in the second MIKE BASIN model which computed supplies and deficits as per allocation policy among users (M.P. \& U.P.).

\section{Methodology}

The MIKE BASIN based decision support has been developed for water sharing, irrigation management, and planning in command of MP part of the Rangawan reservoir. The rule curve recognizes a reservoir as single physical storage and all users have been connected to it to draw water from the 
TABLE 2: Different scenarios generated for irrigation water management.

\begin{tabular}{|c|c|c|}
\hline S. N. & Description of scenarios & Name \\
\hline 1. & $\begin{array}{l}\text { Average/wet year, conveyance efficiency } 60 \% \text { and } \\
\text { application efficiency } 70 \% \text {. }\end{array}$ & ACP-1 \\
\hline 2. & $\begin{array}{l}\text { Average/wet year, conveyance efficiency } 60 \% \text {, } \\
\text { application efficiency } 70 \% \text {, and using ground } \\
\text { water fraction } 20 \% \text {. }\end{array}$ & ACP-2 \\
\hline 3. & $\begin{array}{l}\text { Average/wet year, conveyance efficiency } 70 \% \text { and } \\
\text { application efficiency } 80 \% \text {. }\end{array}$ & ACP-3 \\
\hline 4. & $\begin{array}{l}\text { Average/wet year, conveyance efficiency } 70 \% \text {, } \\
\text { application efficiency } 80 \% \text {, and using ground } \\
\text { water fraction } 20 \% \text {. }\end{array}$ & $\mathrm{ACP}-4$ \\
\hline 5. & $\begin{array}{l}\text { Dry year, conveyance efficiency } 60 \% \text { and } \\
\text { application efficiency } 70 \% \text {. }\end{array}$ & ACP-5 \\
\hline 6. & $\begin{array}{l}\text { Dry year, conveyance efficiency } 60 \% \text {, application } \\
\text { efficiency } 70 \% \text {, and using ground water fraction } \\
20 \% \text {. }\end{array}$ & ACP-6 \\
\hline 7. & $\begin{array}{l}\text { Dry year, conveyance efficiency } 70 \% \text { and } \\
\text { application efficiency } 80 \% \text {. }\end{array}$ & ACP-7 \\
\hline 8. & $\begin{array}{l}\text { Dry year, conveyance efficiency } 70 \% \text {, application } \\
\text { efficiency } 80 \% \text {, and using ground water fraction } \\
20 \% \text {. }\end{array}$ & ACP-8 \\
\hline 9. & $\begin{array}{l}75 \% \text { probable storage, conveyance efficiency } 60 \% \text {, } \\
\text { and application efficiency } 70 \% \text {. }\end{array}$ & ACP-9 \\
\hline 10. & $\begin{array}{l}75 \% \text { probable storage, conveyance efficiency } 60 \% \text {, } \\
\text { application efficiency } 70 \% \text {, and using ground } \\
\text { water fraction } 20 \% \text {. }\end{array}$ & ACP-10 \\
\hline 11. & $\begin{array}{l}75 \% \text { probable storage, conveyance efficiency } 70 \% \text {, } \\
\text { and application efficiency } 80 \% \text {. }\end{array}$ & ACP-11 \\
\hline 12. & $\begin{array}{l}75 \% \text { probable storage, conveyance efficiency } 70 \% \text {, } \\
\text { application efficiency } 80 \% \text {, and using ground } \\
\text { water fraction } 20 \% \text {. }\end{array}$ & ACP-12 \\
\hline
\end{tabular}

TABLE 3: Details of soils and irrigation data for Rangawan command.

\begin{tabular}{llcc}
\hline S. N. & Description & \multicolumn{2}{c}{ Rangawan command } \\
\hline $1 \quad$ Soil details & Soil 1 & Soil 2 \\
& Field capacity (friction) & 0.12 & 0.2 \\
& Wilting point (friction) & 0.03 & 0.07 \\
& Initial water content (friction) & 0.1 & 0.15 \\
& Depth of evaporable layer (m) & 0.01 & 0.01 \\
& Porosity (friction) & 0.35 & 0.45 \\
Irrigation details & \multicolumn{2}{c}{ Flooding } \\
$\quad$ Irrigation method & \multicolumn{2}{c}{0.7} \\
$\quad$ Wetting fraction & (RAW) 0.05 \\
& Trigger option (friction) & (RAW) 0.8 \\
Application option (friction) &
\end{tabular}

storage. The allocation pool of the reservoir has a physical storage, but the individual user has certain storage rights within a zone of water levels. The lakes are specific reservoirs for which no operation rules are applied [33]. Water sharing
TABLE 4: Details of sowing date, crops, and cropped area of existing cropping pattern.

\begin{tabular}{lcccc}
\hline S. N. & Crops & $\begin{array}{c}\text { Area under } \\
\text { soil 1 (ha) }\end{array}$ & $\begin{array}{c}\text { Area under soil } \\
\text { 2 (ha) }\end{array}$ & $\begin{array}{c}\text { Date of } \\
\text { sowing }\end{array}$ \\
\hline 1 & Wheat 1 & 330.73 & 374.45 & 25 October \\
2 & Wheat 2 & 661.45 & 748.90 & 1 November \\
3 & Wheat 3 & 330.73 & 374.45 & 11 November \\
4 & Gram & 853.50 & 966.34 & 20 November \\
\hline
\end{tabular}

in MIKE BASIN is possible through allocation pool reservoir where computation of irrigation demand from command is not possible and hence, in the proposed DSS, two different MIKE BASIN models have been developed. The first model has been formulated to compute the irrigation demand from commands under variable scenarios of rainfall, reservoir storages, crops, and climate and the results of the first model have been used as inputs to the second model, which computes irrigation supplies, demand deficit, reservoir storages, and so forth, for different users according to their water shares. A flow chart showing development and application of DSS for water management in the Rangawan reservoir is presented in Figure 2.

5.1. Simulation Runs for Irrigation Demand. For estimation of irrigation demands, MIKE BASIN model was setup which consists of a catchment and reservoir operated as rule curve reservoir connected to command node having areas of crops in different soil groups. All the submodels required for computation of crop water requirement have been defined and simulation runs have been made. The impact of climatic variability on water requirement was represented by changing rainfall and climatic parameters in climate submodel. The output files of this simulation run contained evapotranspiration, total irrigation demand, net flow, demand deficit, stored volume, channel flows, and water levels in reservoirs at given time span assigned during simulation.

5.2. Simulation Runs for Water Sharing. To manage water sharing between the states and determine supply and deficit/ excess, the irrigation demands estimated from the first model in different periods have been used as user demands of water in the second model. The second model consists of a reservoir and catchment node in which the reservoir node is connected with the two water users (MP and UP) through connecting channels. The general properties of the reservoir were defined as allocation pool reservoir where all available and incoming water was divided as per designated share of users. The field investigations indicated that about 15 to $25 \%$ irrigation demand is met through localized pumping of groundwater. Thus, $20 \%$ use of groundwater was assigned in the properties of user node to make the model capable of consumptive use. The results of simulation run of this model provided demand and demand deficit of users, net flow at various nodes, and water level and stored volume of the reservoir at given time span assigned for the simulation. 


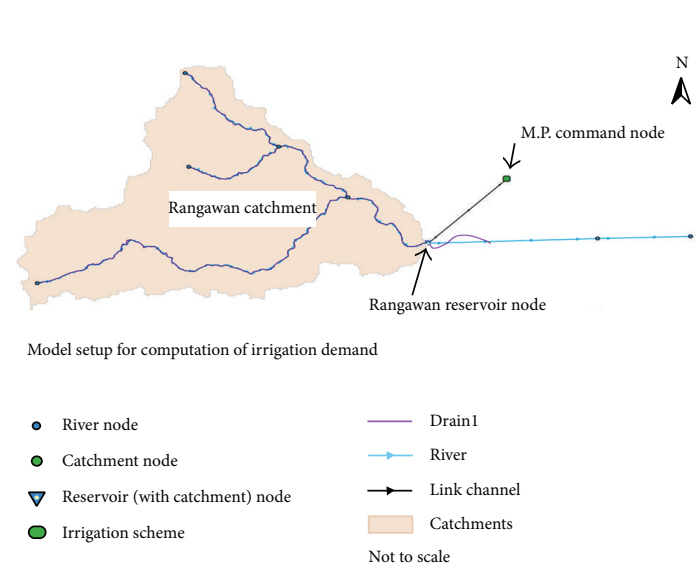

(a) Model setup for computation of irrigation demand

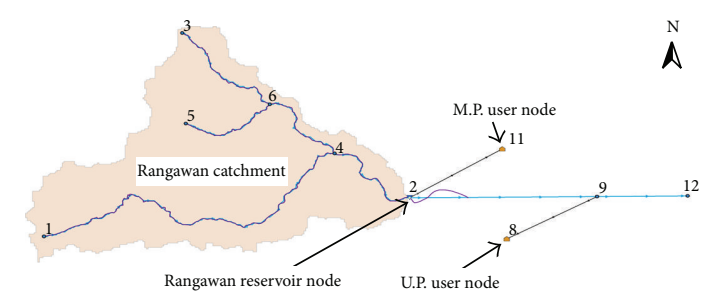

Model setup for water sharin

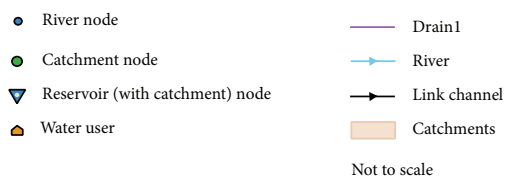

(b) Model setup for water sharing

FIGURE 3: MIKE BASIN model setup of the Rangawan reservoir for computation of different scenarios.

TABLE 5: Irrigation demand, water used, and deficit from MIKE BASIN results in ACP.

\begin{tabular}{|c|c|c|c|c|c|c|}
\hline \multirow{2}{*}{ Scenarios } & \multirow{2}{*}{ Demand $\left(\mathrm{Mm}^{3}\right)$} & \multicolumn{3}{|c|}{ Water used $\left(\mathrm{Mm}^{3}\right)$} & \multirow{2}{*}{ Deficit $\left(\mathrm{Mm}^{3}\right)$} & \multirow{2}{*}{ Excess $\left(\mathrm{Mm}^{3}\right)$} \\
\hline & & Reservoir & Groundwater & Total water & & \\
\hline ACP-1 & 11.83 & 11.83 & 0.00 & 11.83 & 0.00 & 1.84 \\
\hline ACP-2 & 11.83 & 9.51 & 2.32 & 11.83 & 0.00 & 3.08 \\
\hline ACP-3 & 11.83 & 11.83 & 0.00 & 11.83 & 0.00 & 3.58 \\
\hline $\mathrm{ACP}-4$ & 11.83 & 9.51 & 2.32 & 11.83 & 0.00 & 4.64 \\
\hline ACP-5 & 16.77 & 10.39 & 0.00 & 10.39 & 6.38 & 0.00 \\
\hline ACP-6 & 16.77 & 10.14 & 3.28 & 13.42 & 3.35 & 0.00 \\
\hline ACP-7 & 16.77 & 13.57 & 0.00 & 13.57 & 3.2 & 0.00 \\
\hline ACP-8 & 16.77 & 13.22 & 3.28 & 16.50 & 0.27 & 0.00 \\
\hline ACP-9 & 11.83 & 11.83 & 0.00 & 11.83 & 0.00 & 1.35 \\
\hline ACP-10 & 11.83 & 9.51 & 2.32 & 11.83 & 0.00 & 2.73 \\
\hline ACP-11 & 11.83 & 11.83 & 0.00 & 11.83 & 0.00 & 3.08 \\
\hline ACP-12 & 11.83 & 9.51 & 2.32 & 11.83 & 0.00 & 4.14 \\
\hline
\end{tabular}

\section{Results and Discussion}

6.1. Results. MIKE BASIN based DSS developed for operation and management of irrigation in the command of the Rangawan reservoir has been extended to generate 12 different scenarios for actual average cropping pattern under changing climatic variables, storages, groundwater uses, and losses during conveyance and application of water (Table 2). The models derived for computation of crop water requirement and subsequently to supply irrigation water under water sharing agreement have been presented in Figure 3. In allocation pool operating rule, pool ownerships have been defined for allocation of water to the water users (MP and UP) in terms of fraction of total storage and fraction of inflow available for the reservoir operation.

For simulation runs of different scenarios, necessary changes in the values of the reservoir inflows, channel, and various submodels for computation of crop water requirements have been made. The data gathered from field investigations on infiltration, soil water retention, and porosity were used in the model for computation of amount of water stored in the soil. Analyzed results of the soil testing indicated the soils have two major groups, which are presented in Table 3. The details of crops under existing cropping pattern are given in Table 4. For planning of irrigation management and efficient operation of the Rangawan project, probability analysis has been carried out based on the annual reservoir storage data of 18 years with probability of occurrence at $75 \%$ $\left(48.63 \mathrm{Mm}^{3}\right)$.

The water used and deficit/excess for the Rangawan command under different scenarios have been presented in Figure 4 and Table 5. In scenarios, where the irrigation demand was met completely, the excess water available to MP as per the water sharing agreement has been computed after deducting dead storage and losses due to evaporation and seepage. From the analysis of simulated results for ACP in average/wet rainfall year and conveyance efficiency of $60 \%$ and application efficiency of $70 \%$, the irrigation demand of $11.83 \mathrm{Mm}^{3}$ has been met completely and $1.84 \mathrm{Mm}^{3}$ of excess water has been found available for MP (ACP-1). The scenario ACP-4 showed availability of $4.64 \mathrm{Mm}^{3}$ water to MP 


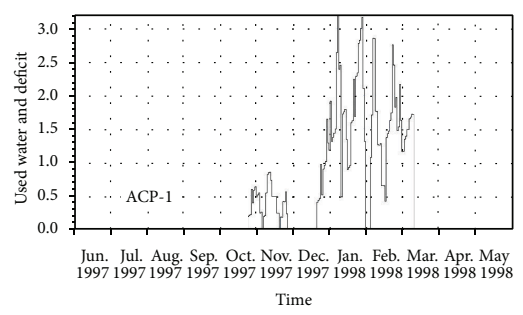

(a)

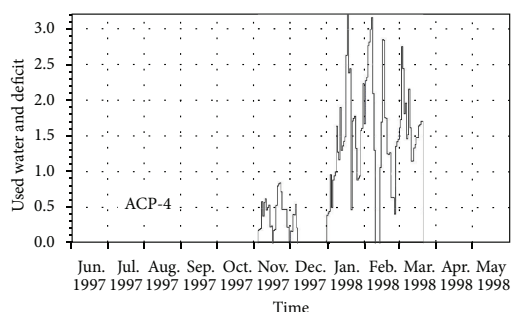

(d)

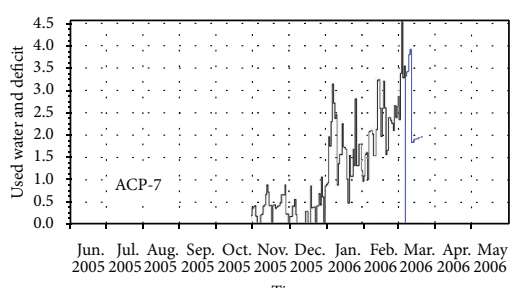

Time

(g)

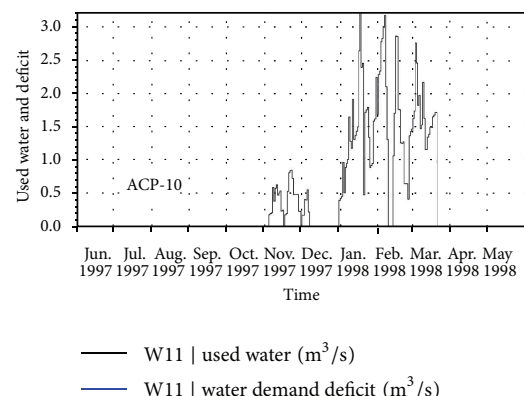

(j)

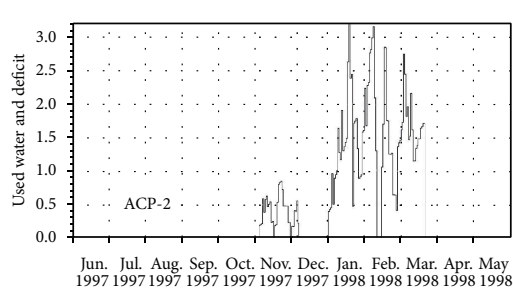
Time

(b)

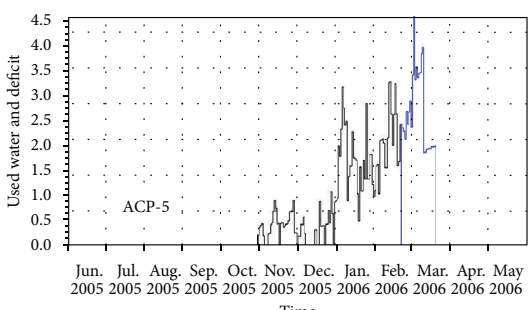

Time

(e)

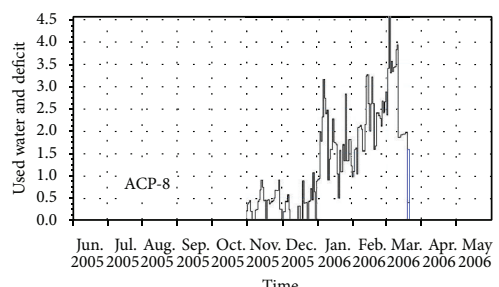

(h)

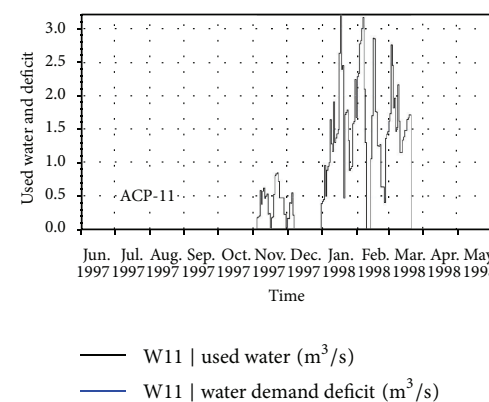

(k)

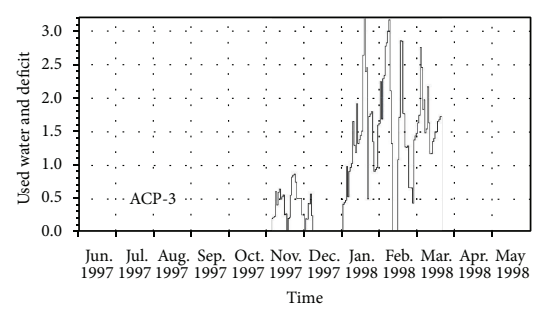

(c)

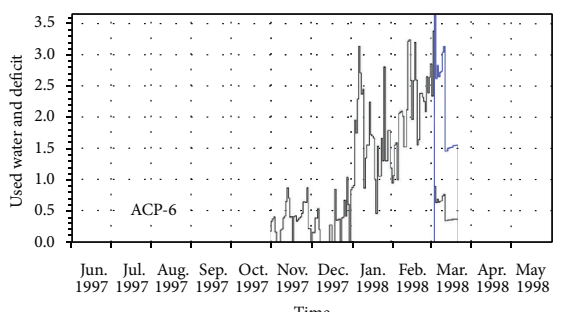

Time

(f)

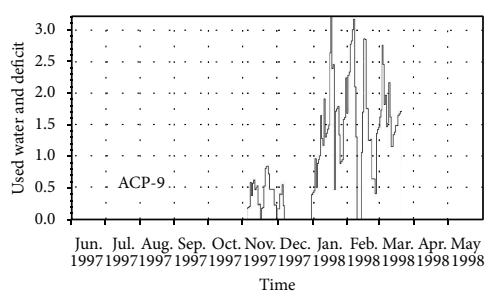

(i)

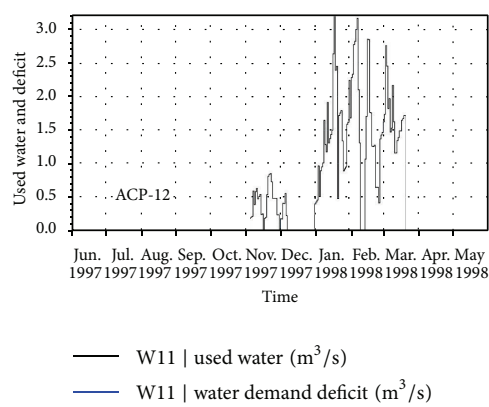

(l)

Figure 4: Demand deficit and used water for different scenarios (ACP-1 to ACP-12) in Madhya Pradesh part of the Ranagawan command.

after fulfilling all the irrigation demands of the Rangawan command. These results are on the expected lines. Thus it can be postulated that the developed DSS can be used for efficient irrigation management and reservoir operation.

For the dry rainfall year, when the rainfall has been insufficient to fill up the reservoir completely, with conveyance efficiency of $60 \%$ and application efficiency of $70 \%$, the irrigation demand, used water, and demand deficit have been estimated to be $16.77 \mathrm{Mm}^{3}, 10.39 \mathrm{Mm}^{3}$, and $6.38 \mathrm{Mm}^{3}$, respectively (ACP-5). With use of $20 \%$ groundwater in conjunction with the reservoir water, the demand deficit reduced to $3.35 \mathrm{Mm}^{3}$ (ACP-6). If conveyance efficiency is increased to $70 \%$ and application efficiency to $80 \%$, the demand deficit reduced to $3.20 \mathrm{Mm}^{3}$ (ACP-7) and for use of $20 \%$ groundwater, the deficit further reduced to $0.27 \mathrm{Mm}^{3}$
(ACP-8). From the simulation run on $75 \%$ probable storage with conveyance efficiency of $60 \%$ and application efficiency of $70 \%$, respectively (ACP-9), the reservoir has been found to fulfill the total demand of $11.83 \mathrm{Mm}^{3}$, but for increasing conveyance and application efficiencies of $70 \%$ and $80 \%$, respectively, and use of groundwater (20\%), the irrigation intensity has been found increased and more areas can be brought under the coverage of irrigation (ACP-12).

6.2. Discussion. The developed DSS tool for the Rangawan reservoir system has been found capable of simulating reservoir operation policy and irrigation supplies management on real time basis under variable rainfall, climate, storages, consumptive use, and crop areas conditions. The DSS requires data of soils, rainfall, cropping pattern, and reservoir storages 
for resolving water sharing issues between users and for managing available water for optimum crop production. Twelve different possible scenarios developed by using the DSS indicated, under likely situations, that the system works effectively in fulfillment of irrigation requirements of MP part in average/wet years with conveyance efficiency of $60 \%$ and application efficiency of $70 \%$. The analysis of supplies and excess/deficit at irrigation node for different scenarios indicated availability of excess water in MP part in scenarios ACP-1 to ACP-4 and ACP-9 to ACP-12, which can be used to irrigate additional areas. The demand and supply scenarios in dry rainfall years confirmed that the present share of water in MP part is not adequate to fulfill the demand of $16.77 \mathrm{Mm}^{3}$ under drought condition. Reduction in conveyance loss, improvement in application efficiencies, and consumptive use of reservoir water and groundwater can reduce the demand deficit from $6.38 \mathrm{Mm}^{3}$ (ACP-5) to $0.27 \mathrm{Mm}^{3}$ (ACP-8).

\section{Conclusions}

The efficient water management in canal command area is essential to improve the performance of irrigation project. In the present study, Arc GIS based MIKE BASIN simulation package designed for analyzing water sharing problems has been used for development of a decision support tool for irrigation water management in the command of the Rangawan reservoir. Two cascading type models, with use of outputs from the first as inputs to the second, have been developed. The first model describes the rule curve reservoir for computation of irrigation demand and the second model is directed to simulate reservoir as allocation pool reservoir for enabling the model to compute the water sharing components between two different users. The irrigation module of the first model computes the total irrigation demands, which are used as inputs to the second model that calculates supply, demand deficit, and corresponding reservoir level/volume as per sharing arrangement.

A total of 12 simulation scenarios based on actual cropping pattern (ACP) have been developed. The irrigation demand of ACP in average/wet year has been found to be about $11.83 \mathrm{Mm}^{3}$ for ACP-1 to ACP-4, which fulfilled all criteria without any deficit. It has been noted that the present system has been running at nearly $50 \%$ efficiency; further improvement on conveyance and application efficiency can bring more area under irrigation during average/wet rainfall years. During dry years, the demand deficit of actual cropping pattern estimated to be $6.38 \mathrm{Mm}^{3}$ for conveyance efficiency of $60 \%$ and application efficiency of $70 \%$ can be reduced to $0.27 \mathrm{Mm}^{3}$ by reducing losses and by adopting releases as suggested in ACP-8. The developed MIKE BASIN based DSS can successfully be used for real time reservoir operation and irrigation planning of other reservoirs using crops, reservoir characteristics, and meteorological data.

\section{Conflict of Interests}

The authors declare that there is no conflict of interests regarding the publication of this paper.

\section{References}

[1] R. Oliveira and D. P. Loucks, "Operating rules for multireservoir systems," Water Resources Research, vol. 33, no. 4, pp. 839-852, 1997.

[2] F. Chang, L. Chen, and L. Chang, "Optimizing the reservoir operating rule curves by genetic algorithms," Hydrological Processes, vol. 19, no. 11, pp. 2277-2289, 2005.

[3] C. B. Paderson, H. Medson, and C. S. Kotner, "Real time optimization of dam releases using multi objectives, application to Orange-Fish-Sundays river basin South Africa," in Proceedings of the 13th SANCIAHS Symposium, 2007.

[4] S. K. Jaiswal, M. K. Varma, and M. Gupta, "Planning for optimum use of water resources of MRP complex using MIKE BASIN," Journal of Indian Water Resources Society, vol. 33, no. 1, pp. 15-22, 2013.

[5] D. L. Martin, D. G. Watts, and J. R. Gilley, "Model and production function for irrigation management," Journal of Irrigation and Drainage Engineering, vol. 110, no. 2, pp. 149-164, 1984.

[6] R. W. Koch and R. L. Allen, "Decision support system for local water management," Journal of Water Resources Planning \& Management, vol. 112, no. 4, pp. 527-541, 1986.

[7] N. Arumugam and S. Mohan, "Integrated decision support system for tank irrigation system operation," Journal of Water Resources Planning and Management, vol. 123, no. 5, pp. 266273, 1997.

[8] P. P. Mujumdar and T. S. V. Ramesh, "Real-time reservoir operation for irrigation," Water Resources Research, vol. 33, no. 5, pp. 1157-1164, 1997.

[9] S. Prajamwong, G. P. Merkley, and R. G. Allen, "Decision support model for irrigation water management," Journal of Irrigation and Drainage Engineering, vol. 123, no. 2, pp. 106-113, 1997.

[10] D. P. Panigrahi and P. P. Mujumdar, "Reservoir operation modelling with fuzzy logic," Water Resources Management, vol. 14, no. 2, pp. 89-109, 2000.

[11] E. Manoli, G. Arampatzis, E. Pissias, D. Xenos, and D. Assimacopoulos, "Water demand and supply analysis using a spatial decision support system," Global Nest, vol. 3, no. 3, pp. 199-209, 2001.

[12] A. Cancelliere, G. Giuliano, A. Ancarani, and G. Rossi, "A neural networks approach for deriving irrigation reservoir operating rules," Water Resources Management, vol. 16, no. 1, pp. 71-88, 2002.

[13] M. J. Reddy and D. N. Kumar, "Optimal reservoir operation using multi-objective evolutionary algorithm," Water Resources Management, vol. 20, no. 6, pp. 861-878, 2006.

[14] M. J. Reddy and D. N. Kumar, "Optimal reservoir operation for irrigation of multiple crops using elitist-mutated particle swarm optimization," Hydrological Sciences Journal, vol. 52, no. 4, pp. 686-701, 2007.

[15] T. El-Mesiry, E. F. Abdallh, M. S. Gaballah, and S. A. Ouda, "Using yield-stress model in irrigation management for wheat grown under saline conditions," Australian Journal of Basic and Applied Sciences, vol. 1, no. 4, pp. 600-609, 2007.

[16] T. Kim, J. Heo, D. Bae, and J. Kim, "Single-reservoir operating rules for a year using multiobjective genetic algorithm," Journal of Hydroinformatics, vol. 10, no. 2, pp. 163-179, 2008.

[17] J. Cañón, J. González, and J. Valdés, "Reservoir operation and water allocation to mitigate drought effects in crops: a multilevel 
optimization using the drought frequency index," Journal of Water Resources Planning and Management, vol. 135, no. 6, pp. 458-465, 2009.

[18] F. F. Li, J. H. Wei, X. D. Fu, and X. Y. Wan, "An effective approach to long-term optimal reservoir operation of large scale reservoir system: case study of three Gorge system," Water Resources Management, vol. 26, no. 12, pp. 4073-4090, 2012.

[19] M. Hosseini, S. J. Mousavi, A. Ardeshir, and K. Behzadian, "Flood control operation of a multi-reservoir system using system dynamics-based emulation-optimization Model," in International Conference on Flood Resilience, University of Exeter, Exeter, UK, September 2013.

[20] M. R. Nikoo, A. Karimi, and R. Kerachian, "Optimal longterm operation reservoir-river systems under hydrologic uncertainties: application of interval programming," Water Resources Management, vol. 27, no. 11, pp. 3865-3883, 2013.

[21] H. Wang and J. Liu, "Reservoir operation incorporating hedging rules and operational inflow forecast," Water Resources Management, vol. 27, no. 5, pp. 1427-1438, 2013.

[22] A. B. Darriane and S. Sarain, "Application intelligent water drops algorithm in reservoir operation," Water Resources Management, vol. 27, no. 14, pp. 4827-4843, 2013.

[23] M. Moghaddasi, S. Araghinejad, and S. Morid, "Water management of irrigation dams considering climatic variation: case study of Zagndeh-rud reservoir, Iran," Water Resources Management, vol. 27, no. 6, pp. 1651-1660, 2013.

[24] M. Ahmadi, O. B. Hadded, and M. A. Marino, "Extraction of flexible multi-objective real time reservoir operation rule," Water Resources Management, vol. 28, no. 1, pp. 131-147, 2014.

[25] V. Rajasekaram and K. D. Nandalal, "Decision support system for reservoir water management conflict resolution," Journal of Water Resources Planning and Management, vol. 131, no. 6, pp. 410-419, 2005.

[26] M. K. Goel, S. K. Jain, V. Kumar, and A. Sharma, "Models for water resources assessment and reservoir operation simulation in a multi-basin," Jalvigyan Sameeksha, Roorkee India, vol. 19, pp. 73-88, 2004.

[27] S. Raut, K. S. S. Sarma, and D. K. Das, "Study of irrigation and crop water requirements and growth of two Rabi crops grown in a semi arid region using agrometeorology and remote sensing," Journal of Indian Society of Remote Sensing, vol. 38, no. 2, pp. 321-331, 2010.

[28] L. N. Sethi, D. N. Kumar, S. N. Panda, and B. C. Mal, "Optimal crop planning and conjunctive use of water resources in a coastal river basin," Water Resources Management, vol. 16, no. 2, pp. 145-169, 2002.

[29] C. C. Yang, L. C. Chang, C. S. Chen, and M. S. Yeh, "Multiobjective planning for conjunctive use of surface and subsurface water using genetic algorithm and dynamics programming," Water Resources Management, vol. 23, no. 3, pp. 417-437, 2009.

[30] H. R. Safavi, F. Darzi, and M. A. Mariño, "Simulation-optimization modeling of conjunctive use of surface water and groundwater," Water Resources Management, vol. 24, no. 10, pp. 1965-1988, 2010.

[31] DHI, MIKE BASIN-GIS-based Water Resource Modeling Package, 2009.

[32] M. K. Jha and A. Das Gupta, "Application of Mike Basin for water management strategies in a watershed," Water International, vol. 28, no. 1, pp. 27-35, 2003.

[33] L. L. Ngo, H. Madsen, D. Rosbjerg, and C. B. Pedersen, "Implementation and comparison of reservoir operation strategies for the Hoa Binh reservoir, Vietnam using the Mike 11 model," Water Resources Management, vol. 22, no. 4, pp. 457-472, 2008.

[34] FAO, Crop Evapotranspiration-Guidelines for Computing Crop Water Requirements, Irrigation and Drainage Paper No. 56, 1998, http://www.fao.org/nr/water/docs/CROPWAT8.0Example.pdf. 


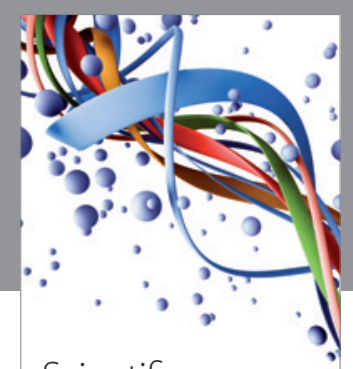

Scientifica
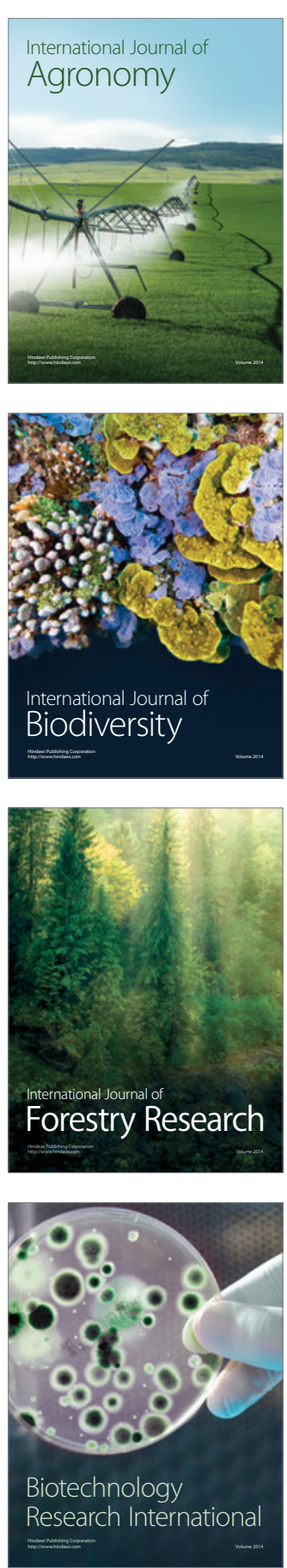
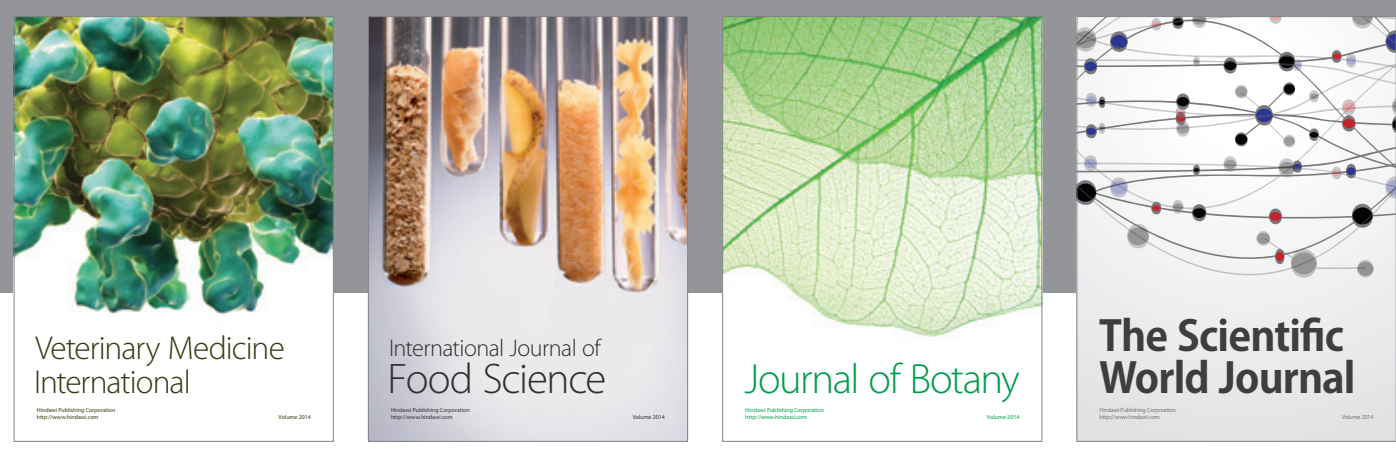

The Scientific World Journal
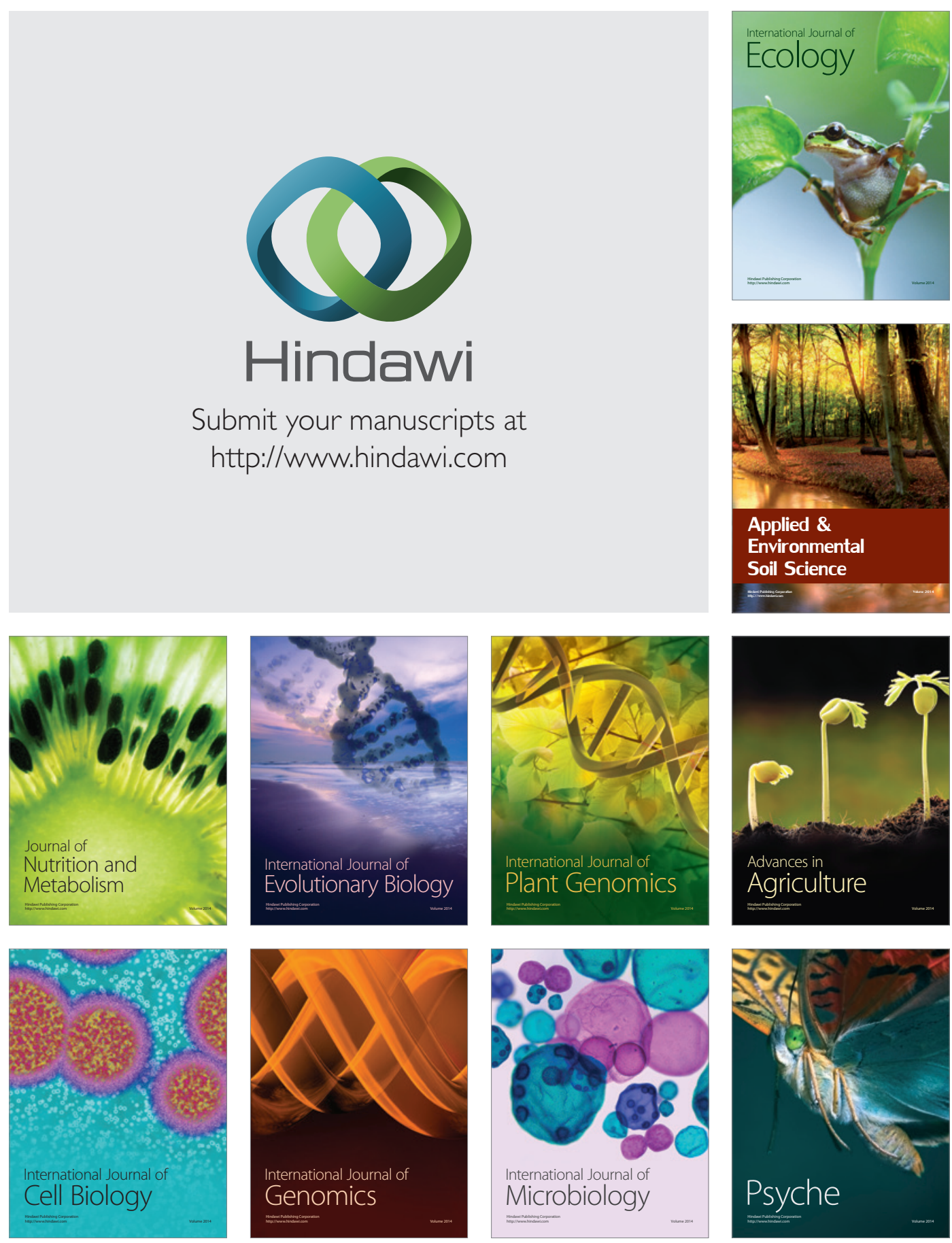